\title{
SILVER(I) PRECONCENTRATION USING $m$-AMINOPHENOL CONTAINING SORBENT FROM AQUEOUS SOLUTIONS
}

\author{
N.T.Afandiyeva, A.M.Maharramov, F.M.Chiragov \\ Baku State University \\ afandiyeva.narmin@mail.ru
}

Received 14.05.2019

Accepted 09.09.2020

\begin{abstract}
The influence of sorption characteristics on the removal of silver(I) has been examined. The sorption capacity of chelating polymeric sorbent, based on maleic anhydride styrene copolymer modified with $\mathrm{m}$ aminophenol, towards $\mathrm{Ag}(\mathrm{I})$ ions was studied. The $\mathrm{pH}$ of sorption was maximum at the value 6 . With the increasing of initial metal concentration, sorption of silver(I) increases and reached maxima at value $80 \cdot 10^{-3} \mathrm{M}$. At the final stage, the elution process of $\mathrm{Ag}(\mathrm{I})$ was established and find that $\mathrm{HNO}_{3} 1 \mathrm{M}$ is the best elution agent. Multiple use of the regenerated sorbent for sorption process is possible. This study shows that using of mentioned sorbent modified with $m$-aminophenol is effective for removal of silver(I) ions from aqueous solutions.
\end{abstract}

Keywords: preconcentration, removal, silver(I), m-aminophenol, aqueous solution.

doi

\section{Introduction}

Heavy metal ions have a strong ability to collect in objects of environments and consider to be one of it's main pollutants. They can get to human body through different sources, such as aquatic environment and show toxicity even at low doses. So, there is a need to reduce their concentration in environmental samples by using modern analysis methods.

Silver is among of heavy metal ions [1]. Due to the excellent physical properties, such as the highest thermal conductivity it widely used in industry, production of jewellery, coins, photography and etc. On the other hand, being one of the potential toxicants, it's show a big damage to humans life. Increasing content of silver and silver compounds in environment cause several disease, the main and well-known of which is argyria. Therefore, the determination of silver(I) in objects of environment is actual problem.

Various treatment methods, such as sorption, flotation were used to remove silver and its compounds and reduce their concentration [2-20]. Among of them sorption is the most widely used method in recent years. The main advantages of method is simplicity, cost-effectiveness and applicability for the removal of number heavy metal ions from water and wastewater.

Natural adsorbents, such as activated car- bons were used in absorption of chemicals in environmental objects, such as water, because it has an ability to improve water quality by removing the chemicals [20]. On the other hand, it is not effective for adsorption of total dissolved solids as unable by sorption, hardness, or heavy metals. So, there is a need to use the effective adsorbents, which have high sorption capacity and can selectively absorb the heavy metal ions from aqueous solutions.

In recent years, polymeric chelating sorbents are widely used for preconcentration and removal of heavy metal ions, because of number of advantages, such as higher adsorption capacity, selectivity, than natural one. They allow to determine the trace amounts of elements. Especially, nitrogen and sulfur containing sorbents reveals high selectivity towards silver(I) ions in aqueous solutions. Thus, due to the number of advantages polymeric chelating sorbents are widely used for sorption of silver(I) ions from aqueous solutions.

In present work polymeric sorbent of maleic anhydride styrene copolymer (MASC), modified with m-aminophenol was used as an adsorbent for the preconcentration and spectrophotometric determination of silver(I) ions from aqueous solutions. In this regard, the proposed technique is based on the preliminary 
concentration of silver(I) from the object using a polymeric chelating sorbent containing fragments of $m$-aminophenol.

\section{Materials and methods}

Chemicals and Equipment. The chemicals used in the present study were of analytical grade. The stock solution of $\mathrm{Ag}(\mathrm{I})$ was prepared from it's salt $\mathrm{AgNO}_{3}$ by diluting with deionized water till mark. The working solutions were prepared by diluting the appropriate amount of the stock solution. The $\mathrm{pH}$ values were maintained constant by using solutions of $\mathrm{HCl}, \mathrm{NaOH}$ and ammonia-acetate buffer solutions. [21] To maintain a constant ionic strength, a $\mathrm{KCl}$ solution was used. Reagent 2,2'-di(2,3,4-trihydroxyphenylazo)biphenyl (R) was prepared by the azocombination of a diazotized amine with pyrogallol. In order to use in the analysis, the sorbent pellets were ground in an agate mortar and sieved through a sieve with diameter $0.14 \mathrm{~mm}$. Each experiment was repeated twice. To study the sorption of silver, we used a chelating sorbent based on a copolymer of maleic anhydride with styrene, containing fragments of $m$-aminophenol (Scheme 1).

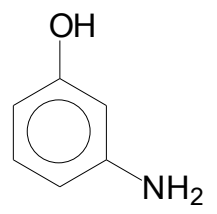

Scheme 1. Molecular structure of $m$-aminophenol.

\section{Adsorbent synthesis}

Adsorbent synthesis was carried out by the known technique [22]. For each experiment $3 \mathrm{~g}$ of maleic anhydride styrene copolymer was measured and the corresponding quantity of amine added to a flask. m-Aminophenol was solved in hot water. Reaction proceeds in the presence of formalin at $330-340 \mathrm{~K}$ and lasts approximately $30-40 \mathrm{~min}$. The reaction is carried out in sandy bath by continuous mixing. Since the reaction is carried out in aquatic environment anhydride groups of copolymer subject to hydrolysis. Because of the mutual influence of formaldehyde and amine nonstable carbonylamine is formed. The resulting carbonylamine mutually interacts with carboxyl groups of mac- romolecule and the amine fragment enters the macromolecule.

For removal of remaining parts of reaction product sorbent has been rinsed several times with distilled water. Then constant mass was dried in vacuum desiccators at $323 \mathrm{~K}$, grinded and skipped through sieve with 0.14 $\mathrm{mm}$ of pore diameter. The resulting product was used as the solid phase in current research.

\section{Adsorption experiments}

Sorption process was carried out under static conditions. For each experiment $2 \mathrm{ml}$ of metal ion solution with a known concentration $\left(10^{-2} \mathrm{~mol} / \mathrm{L}\right)$ was added into $50 \mathrm{ml}$ conical flasks. The $\mathrm{pH}$ of solutions were adjusted with $\mathrm{pH}$ meter Ionomer I-130 by using of $0.1 \mathrm{~mol} / \mathrm{L}$ of $\mathrm{NH}_{4} \mathrm{OH}$ and $0.1 \mathrm{~mol} / \mathrm{L} \mathrm{CH} \mathrm{CHOH}_{3} \mathrm{COO}$. The final concentrations of $\mathrm{Ag}(\mathrm{I})$ ions in the filtrate determined at $\lambda=540 \mathrm{~nm}$.

The absorption capacity of $\mathrm{Ag}(\mathrm{I})$ ions sorbed by sorbent was calculated from the following equation:

$$
Q=\frac{\left(C_{0}-C_{e}\right) V}{m},
$$

where $Q-$ is the sorption capacity of sorbent, $\mathrm{mg} / \mathrm{g}, V$ - volume of solution, $C_{0}-$ is the initial concentration of silver ions $\mathrm{mg} / \mathrm{l}, C$ is the concentration of silver ions after the sorption process $(\mathrm{mg} / \mathrm{l})$ and $m$-mass of the sorbent $(\mathrm{mg})$. The maximum sorption capacity of sorbent with respect to silver ions is $230.4 \mathrm{mg} / \mathrm{g}$.

The percentage recovery of silver ions was calculated by the ratio of the difference in the concentrations of silver ions in the solution before and after sorption to the concentration of silver ions in the solution before sorption using the following equation:

$$
\% R=\frac{C_{0}-C_{e}}{C_{0}} \times 100,
$$

where $R$ is the percentage recovery, $C_{\mathrm{o}}$ and $C_{\mathrm{e}}$ are the initial and equilibrium concentrations of the silver ion. The maximum percentage recovery of silver ions from the solution when using a sorbent modified with $m$-aminophenol was $88 \%$. 


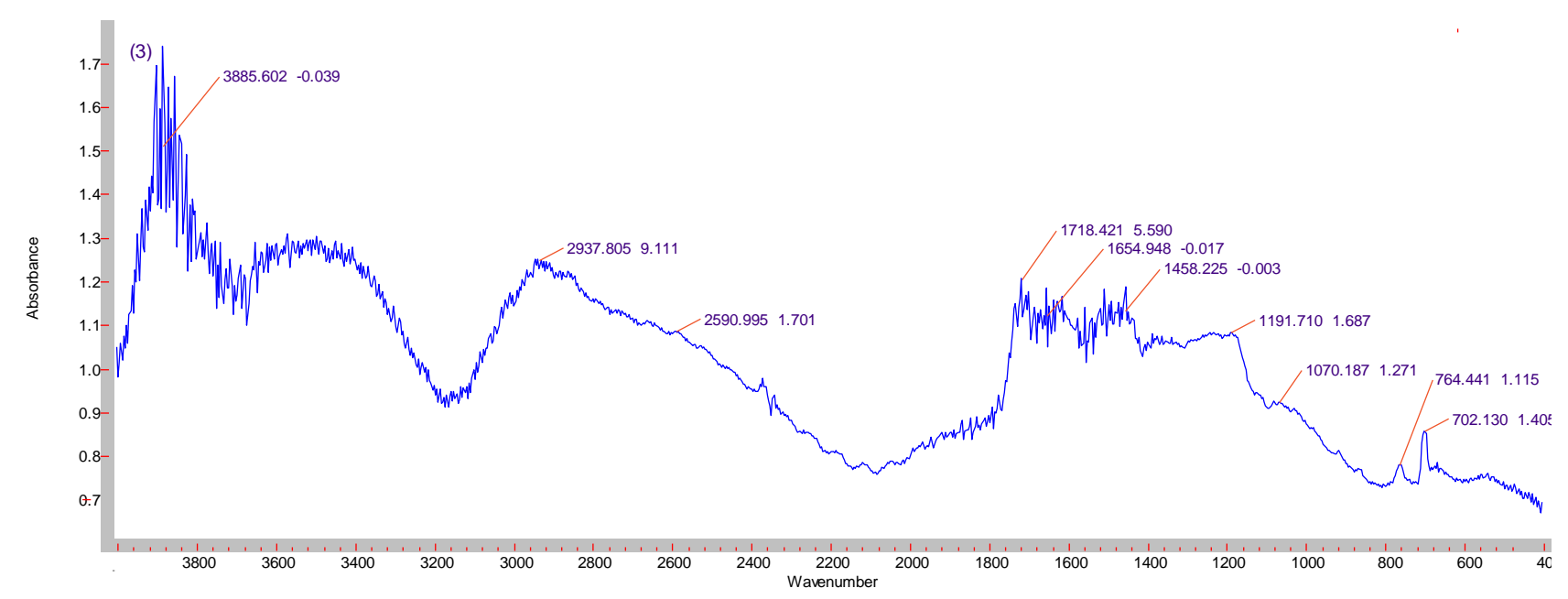

Fig. 1. The FTIR spectra of the sorbent.

\section{Results and discussions}

The structure of the obtained sorbent was studied by FTIR spectroscopy.

\section{FTIR spectroscopy}

The FT-IR spectroscopy of the sorbent has been studied. In IR spectrum of sorbent are observed the following vibrations: stretching dances of NH group at $3400-3200 \mathrm{~cm}^{-1}$, stretching dances of $\mathrm{OH}$ group at $355-3200 \mathrm{~cm}^{-1}$, $-\mathrm{C}=\mathrm{O}$ group stretching dances of carboxyl group at $1750-1715 \mathrm{~cm}^{-1}, \mathrm{C}-\mathrm{N}$ stretching dances and $\mathrm{N}-\mathrm{H}$ deformation dances at 1570 $1550 \mathrm{~cm}^{-1}$, valent dances in benzene ring at $1610-1510 \mathrm{~cm}^{-1}$, deformation dances in benzene ring at $710-680 \mathrm{~cm}^{-1}$.

\section{Influence of $\mathrm{pH}$}

$\mathrm{pH}$ of solution is one the most important characteristics, determining the behavior of ions in aqueous solutions. The effect of $\mathrm{pH}$ on the sorption of silver(I) was studied by varying the $\mathrm{pH}$ within the range of 3-7. Sorption of silver ions was carried out in static conditions from aqueous solutions. Sorption of the silver(I) was carried out from the volume of $25 \mathrm{ml}$ of the solution. Due to this, was added $1.5 \mathrm{ml}$ of the reagent solution to the aliquot part of the sorbent solution with a volume of $1 \mathrm{ml}$ and diluted till mark with $\mathrm{pH}$. The optical density of the solution is measured on a photocolorimeter KFK-2 at $\lambda=440 \mathrm{~nm}$.
The results showed that the recovery of silver was maximized in the $\mathrm{pH}$ of solution 6 . At $\mathrm{pH} 6$ the degree of sorption passes through a maximum. So, the sorption capacity of sorbent was $\mathrm{pH}$ dependent and in order to achieve the maximum efficiency, selectivity of the silver(I) extraction, a $\mathrm{pH}$ of 6 was selected for the subsequent studies.

\section{Influence of contact time}

The effect of contact time on the removal of silver(I) from aqueous solutions was studied. In order to carry out the influence of contact time on adsorption of silver(I) from aqueous solutions, an aliquot part of solution was taken every 30 minutes and analyzed by AAS. Results of two parallel analysis were averaged. By the results, the sorbent is fully saturated with silver(I) after $210 \mathrm{~min}$. The recovery of silver reached $91 \%$. Further increasing in saturation time wasn't significantly change the adsorption. Thus, saturation time of 210 min was chosen for further experiments.

\section{Influence of initial $\mathrm{Ag}^{+}$concentration}

Influence of initial metal concentration is one of the main parameters affecting sorption process. Effect of initial $\mathrm{Ag}(\mathrm{I})$ concentration on sorption was studied. It is found, that with increasing the initial concentration of metal in the solution, sorption of silver ion increases and, reached a maximum at concentration $80 \cdot 10^{-3} \mathrm{M}$ 
$\left(\mathrm{pH} 6, C_{\mathrm{Ag}+}=80 \cdot 10^{-3} \mathrm{M}, V_{\text {total }}=20 \mathrm{ml}, m_{\text {sorbent }}=\right.$ $0.03 \mathrm{~g}$ ). At this value all the $\mathrm{Ag}^{+}$ions are adsorbed by solid phase. Then the sorption process reached equilibria.

\section{Influence of ionic strength}

Effect of ionic strength on sorption of silver(I) was studied. Silver(I) was sorbed from aqueous solutions containing $0.1-1.4 \mathrm{M} \mathrm{KCl}$. The presence of $\mathrm{KCl}$ increased the adsorption capacity due to value of $\mu=0.6$. Further, there is a significant decrease in metal(I) sorption from solutions with a concentration of more than 0.6 M. Therefore, all further experiments were carried out in aqueous solutions with an ionic strength of $0.6 \mathrm{M}$.

\section{Effect of coexisting ions}

The effect of co-existing ions on $\mathrm{Ag}(\mathrm{I})$ adsorption process was studied. By the results of experiments it can be seen, that sorbent could adsorb $\operatorname{Ag}(\mathrm{I})$ ions in the presence of alkali and alkaline-earth ions, such as $\mathrm{Na}^{+}, \mathrm{K}^{+}, \mathrm{Ca}^{2+}$. Transition metals, such as $\mathrm{Zn}^{2+}, \mathrm{Ni}^{2+}, \mathrm{Cr}^{3+}$ and $\mathrm{Pd}^{2+}$ also couldn't prevent to the $\operatorname{Ag}(\mathrm{I})$ adsorption process. This process indicates, that the occurring adsorption is selective and in the same conditions adsorbent could separate more silver(I) ions than other metal ions.

\section{The desorption process}

Desorption and regeneration of the sorbent is the economical process of recovering metal ions. This process allow the repeated use of sorbent. In this process a precipitate of $\mathrm{Ag}^{+}$ with sorbent was formed, filtered off, washed 2-3 times with distilled water in order to remove the diluents, and then dried. As desorbing agents used the $0.5 \mathrm{M}, 1 \mathrm{M}, 1.5 \mathrm{M}, 2 \mathrm{M}$ solutions of $\mathrm{H}_{2} \mathrm{SO}_{4}$ and $\mathrm{HNO}_{3}$. The best elution properties toward silver(I) ions possessed the $1 \mathrm{M}$ nitric acid solution.

The sorption-desorption process is carried out until the used sorbent does not lose its quality in the process of concentration. The results of the studies showed that the copolymer of styrene with maleic anhydride modified with m-aminophenol can be used 7 times for the concentration process without changing its qualities.

\section{Adsorption isotherms}

Adsorption isotherms are used in order to explain the adsorption process between adsorbent and adsorbate. Adsorption isotherms were obtained by varying the initial concentration of $\mathrm{Ag}(\mathrm{I})$ ions from $2 \cdot 10^{-3} \mathrm{~mol} / \mathrm{L}$ to $80 \cdot 10^{-3} \mathrm{~mol} / \mathrm{L}$. The maximum adsorption capacity of adsorbent toward silver(I) was determined using Langmuir isotherm model.

\section{Langmuir adsorption isotherm}

Adsorption of $\operatorname{Ag}(\mathrm{I})$ can be easily explained using Langmuir adsorption isotherm. Langmuir adsorption model based on the assumption that molecules are adsorbed at a fixed adsorption site.

$$
R_{L}=\frac{q_{m} K_{L} C_{e}}{1+K_{L} C_{e}}
$$

where $C_{e}(\mathrm{mg} / \mathrm{L})$ is the equilibrium concentration of $\mathrm{Ag}^{+}$in solution, $\mathrm{q}_{\mathrm{e}}(\mathrm{mg} / \mathrm{g})$ is the equilibrium adsorption capacity, $q_{m}(\mathrm{mg} / \mathrm{g})$ is the adsorption capacity of monolayer and $K_{L}$ $(\mathrm{L} / \mathrm{mg})$ is the Langmuir constant. Langmuir adsorption isotherm constants were calculated from the linear plot of dependence of $\mathrm{C}_{\mathrm{e}} / \mathrm{q}_{\mathrm{e}}$ on $\mathrm{Ce}$, which is shown in Figure 2.

The main characteristic of the Langmuir isotherm is a separation factor $\mathrm{R}_{\mathrm{L}}$, which can be calculated by the following equation:

$$
R_{L}=\frac{1}{1+b C_{0}}
$$

where $b$ is the Langmuir constant $(\mathrm{L} / \mathrm{mmol}), C_{0}$ is the initial concentration of silver(I) ions (mg/L). The value of equilibrium parameter $R_{L}$ between 0 and 1 shows favorable adsorption process. By the results of adsorption study $R_{L}$ found to be 0.996 , which indicates to adsorption favorable by Langmuir model. The value of the regression coefficient $\mathrm{R}^{2}=0.9971$ indicates that Langmuir isotherm model fits good with experimental adsorption data.

Langmuir isotherm parameters for the adsorption of $\mathrm{Ag}(\mathrm{I})$ ions onto adsorbent

\begin{tabular}{|l|c|c|c|c|}
\hline Adsorbent & \multicolumn{4}{|c|}{ Langmuir } \\
\hline & $\left(\mathrm{q}_{\max }, \mathrm{mg} / \mathrm{g}\right)$ & $\left(\mathrm{K}_{\mathrm{L}}, \mathrm{L} / \mathrm{mg}\right)$ & $\left(\mathrm{R}_{\mathrm{L}}\right)$ & $\left(\mathrm{R}^{2}\right)$ \\
\hline$m$-aminophenol & 333.3 & 0.0035 & 0.996 & 0.9971 \\
\hline
\end{tabular}




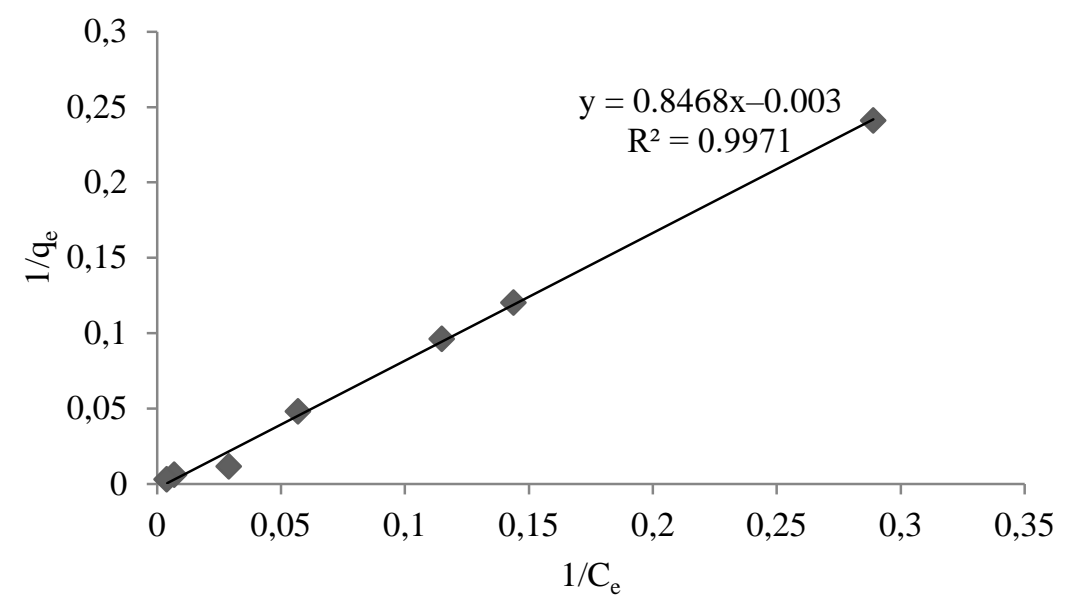

Fig. 2. Langmuir adsorption isotherm.

\section{Conclusions}

Current research represents a very simple, rapid, sensitive and inexpensive method for the selective removal of silver(I) ions from aqueous solutions. This study is characterized by high removal efficiency, which reveals, that MASC modified with m-aminophenol was suitable for removal of silver(I) ions from aqueous media. Various sorption factors, such as $\mathrm{pH}$, contact time, initial metal ion concentration and ionic strength effect the adsorption of silver(I) ions.

\section{References}

1. Hadrup N., Lam H.R. Oral toxicity of silver ions, silver nanoparticles and colloidal silver. Regulatory Toxicology and Pharmacology. 2014. No 1. P. $1-7$.

2. Afandiyeva N.T. Preconcentration of silver(I) on the modified sorbent from aqueous solutions. New Materials, Compounds and Applications. 2020. No 1. P. 54-60.

3. Efendieva N.T., Magerramov A.M., Chyragov F.M. Koncentrirovanie ionov serebra sinteticheskim sorbentom iz vodnykh rastvorov. 2019. № 1. C. 45-49.

4. Vasylechko V.O., Fedorenko V.O., Gromyko O.M., Gryshchouk G.V, Kalychak Y.M, Zaporozhets O.A., Lototska M.T. Solid phase extractive preconcentration of silver from aqueous samples and antimicrobial properties of the clinoptiloliteAg composite. Adsorption Science \& Technology. 2017. No 7. P. 602-611.

5. Ghassabzadeli H., Mohadespour A., Torab-Mostaedi M., Zaheri P., Maragheh M.G., Taheri H. Adsorption of $\mathrm{Ag}, \mathrm{Cu}$ and $\mathrm{Hg}$ from aqueous solutions using expanded perlite. J. Hazardous Maters. 2010. No 1. P. $950-955$.

6. Rofouei M.K., Payehghadr M., Shamsipur M., Ahmadalinezhad A. Solid phase extraction of ultra traces silver(I) using octadecyl silica membrane disks modified by 1,3-bis(2-cyanobenzene) triazene (CBT) ligand prior to determination by flame atomic absorption. J. Hazardous Mater. 2009. No 2. P. $1184-1187$.

7. Fu L., Zhang L., Wang S., Peng J., Zhang G. Selective adsorption of $\mathrm{Ag}^{+}$by silica nanoparticles modified with 3-amino-5-mercapto-1,2,4-triazole from aqueous solutions. J. Molecular Liquids. 2017. P. 292-300.

8. Celik Z., Gülfen M., Aydin A.O. Synthesis of a novel dithiooxamide-formaldehyde resin and its application to the adsorption and separation of silver ions. J. Hazardous Mater. 2010. No 1. P. 556562.

9. Jeon C. Adsorption of silver ions from industrial wastewater using waste coffee grounds. Korean J. Chemical Engineering. 2017. No 2. P. 384-391.

10. Wang S., Li H., Chen X., Yang M., Qi Y. Selective adsorption of silver ions from aqueous solution using polystyrene-supported trimer captotriazine resin. J. Environmental Sciences. 2012. No 12. P. $2166-2172$.

11. Lin G., Wang Sh., Zhang L., Hu T., Peng J., Cheng S., Fu L. Selective adsorption of $\mathrm{Ag}^{+}$on a new cyanuric-thiosemicarbazide chelating resin with high capacity from acid solutions. Polymers. 2017. No 11. P. 568-584.

12. Petrova Y.S., Pestov A.V., Usoltseva M.K., Neudachina L.K. Selective adsorption of silver(I) ions over copper(II) ions on a sulfoethyl derivative of chitosan. J. Hazardous Mater. 2015. P. 696-701.

13. Hou H., Yu D., Hu G. Preparation and Properties of Ion-Imprinted Hollow Particles for the Selective Adsorption of Silver Ions. Langmuir. 2015. P. 1376-1384. 
14. Khunathai K., Inoue K., Ohto K., Kawakita H., Kurata M., Atsumi K., Fukuda H., Alam S. Recovery of Silver Using Adsorption Gels Prepared from Microalgal Residue Immobilized with Functional Groups Containing Sulfur or Nitrogen, Materials. 2017. No 6. P. 636-645.

15. Rasulov A. Yili H. Aisa A. Removal of Silver from Aqueous Solution by Azotobacter chroococcum XU1 Biomass and Exopolysaccharide. Advances in Microbiology. 2015. P. 198-203.

16. Nawaz T., Sengupta S. Silver recovery from greywater: Role of competing cations and regeneration. Separation and Purification Technology. 2017. P. 145-158.

17. Jintakosol T., Nitayaphat W., Adsorption of Silver(I) From Aqueous Solution Using Chitosan/Montmorillonite Composite Beads. Mater. Research. 2016. No 5. P. 114-1121.
18. Zafar S., Khalid N., Mirza M.L. Adsorption capacity of rice husk for silver ions by Langmuir isotherm method. Nucleus. No 4. P. 323-330.

19. Akgul M., Karabakan A., Acar O., Yurum Y. Removal of silver(I) from aqueous solutions with clinoptilolite, Microporous and Mesoporous Material. 2006. P. 99-104.

20. Feist B., Mikula B.. Preconcentration of heavy metals on activated carbon and their determination in fruits by inductively coupled plasma optical emission spectrometry. Food Chemistry. 2014. P. 302-306.

21. Mammadov P.R., Afandiyeva N.T., Chiragov F.M. Simple and rapid spectrophotometric determination method for trace level of silver using 2,2'-di (2,3,4- trihidroksifenilazo)bifenil. 2018. No 2. P. 123-131.

22. Akperov O.H., Akperov E.O. Baku, 2002. 231 p.

23. Freundlich H.M.F. Über die adsorption in lösungen Z. Phys. Chemi. 1906. P. 385-470.

\section{GÜMÜŞ(I)-in $m$-AMINOFENOL FRAQMENTLİ SORBENTLə SULU MəHLULLARDAN QATILAŞDIRILMASI}

\section{N.T.əfəndiyeva, A.M.Məhərrəmov, F.M.Çıraqov}

Sorbsiya parametrlərinin gümüş(I)-in çıxarılmasına təsiri öyrənilmişdir. Malein anhidridi stirol sopolimeri əsasında, maminofenol ilə modifikasiya olunmuş xelatəmələgətirici polimer sorbentin $\mathrm{Ag}(\mathrm{I})$-ə qarşı sorbsiya tutumu öyrənilmişdir. Sorbsiya pH 6 qiymətində maksimum olur. Metalın ilkin qatılı̆̆ artdıqca, gümüş(I)-in sorbsiyası artır və $80 \cdot 10^{-3} \mathrm{M}$ maksimum olur. Son mərhələdə, $\mathrm{Ag}(\mathrm{I})$-in desorbsiya prosesi öyrənilmiş və $1 \mathrm{M} \mathrm{HNO}_{3}$-ün ən yaxş1 elyurəedici agent olduğu müəyyənləşdi. Bərpa olunmuş sorbentin sorbsiya prosesi üçün çoxlu sayda istifadəsi mümkündür. Hazırki araşdırma göstərir ki, anhidridi stirol sopolimeri əsasında, m-aminofenol ilə modifikasiya olunmuş xelatəmələgətirici polimer sorbentin istifadəsi gümüş(I)-in sulu məhlullardan çıxarılması üçün effektivdir.

Keywords: qatilaşdirilma, çıxarllma, gümüş(I), m-aminofenol, sulu məhlul.

\section{КОНЦЕНТРИРОВАНИЕ СЕРЕБРА(І) СОРБЕНТОМ, СОДЕРЖАЩИМ $m$-АМИНОФЕНОЛ, ИЗ ВОДНЫХ РАСТВОРОВ}

\section{Н.Т.Эфендиева, А.М.Магеррамов, Ф.М.Чырагов}

Изучено влияние сорбционных характеристик на извлечение серебра(I). Изучена сорбционная ёмкость хелатообразующего полимерного сорбента на основании малеинового ангидрида со стиролом, модифицированного $\mu$-аминофенолом по отношению к ионам $\mathrm{Ag}(\mathrm{I})$. Сорбция максимальна при $\mathrm{pH} 6 . \mathrm{C}$ увеличением начальной концентрации металла сорбция серебра(I) увеличивается и достигает максимума при значении $80 \cdot 10^{-3} \mathrm{M}$. Изучен также процесс десорбции $\mathrm{Ag}(\mathrm{I})$ и найдено, что $1 \mathrm{M} \mathrm{HNO}_{3}$ является лучшим элюирующим агентом. Возможно многократное использование регенерированного сорбента для процесса сорбции. Данное исследование показывает, что использование хелатообразующего полимерного сорбента на основании малеинового ангидрида со стиролом, модифицированного $м$-аминофенолом является эффективным для извлечения серебра(I) из водных растворов.

Ключевые слова: концентрирование, извлечение, серебро(I), м-аминофенол, водный раствор. 